\title{
Säilöntäaineen ja -ajan vaikutus hukkakauran itävyyteen jyväsäilönnässä
}

\author{
Heikkilä, T. ${ }^{1)}$, Saarisalo, E. ${ }^{1,5)}$, Khalili, H. ${ }^{1)}$, Jalli, H. ${ }^{2)}$, Köylijärvi, S. ${ }^{3)}$, Poikulainen, J. ${ }^{3)}$, Vallivaara- \\ Pasto, R. ${ }^{3)}$ ja Jaakkola, S. ${ }^{4)}$ \\ ${ }^{1)}$ Maa- ja elintarviketalouden tutkimuskeskus MTT / Kotieläintuotannon tutkimus, 31600 Jokioinen \\ ${ }^{2)}$ Maa-ja elintarviketalouden tutkimuskeskus MTT / Kasvintuotannon tutkimus, Kasvinsuojelu, 31600 \\ Jokioinen, etunimi.sukunimi@mtt.fi \\ ${ }^{3)}$ Elintarviketurvallisuusvirasto Evira, PL 111, 32201 Loimaa, etunimi.sukunimi@evira.fi \\ ${ }^{4)}$ Helsingin yliopisto, Maataloustieteiden laitos, PL 28, 00014 Helsingin yliopisto, \\ etunimi.sukunimi@helsinki.fi \\ ${ }^{5)}$ Nykyinen osoite: Maa- ja metsätalousministeriö, Elintarvike- ja terveysosasto, PL 30, 00023 Valtio- \\ neuvosto, etunimi.sukunimi@mmm.fi
}

\section{Tiivistelmä}

Viljan tuoresäilöntämenetelmät, jyvä- ja murskesäilöntä ovat varteenotettavia vaihtoehtoja kuivatukselle öljyn hinnan kallistuessa. Jyväsäilöttäessä vilja puidaan myöhemmin kuin kokoviljasäilörehua korjattaessa ja itävien hukkakauran (Avena fatua L.) siementen riski on suurempi. Tuoresäilönnässä vältetään kuivurin kautta tuleva hukkakauran leviämisriski. Tässä tutkimuksessa selvitettiin, säilyykö hukkakauran siementen itävyys propionihapolla, urealla tai ilmatiiviisti ilman säilöntäainetta jyväsäilötyssä viljassa.

Hukkakaura kerättiin yksityiseltä tilalta hukkakauran saastuttamasta ohrakasvustosta ennen ohran puintia varisemisen estämiseksi. Hukkakauran jälkituleentuminen tapahtui huoneenlämmössä. Säilönnässä käytetty ohra puitiin jyväkosteuden ollessa 25 \% MTT:n pellolta Jokioisilla ja säilöttiin hukkakauran siementen kanssa pieniin koesiiloihin. Kokeessa oli kolme säilöntäainekäsittelyä (ilman säilöntäainetta, propionihappo ja urea), kaksi siilon sulkemistapaa (avoin normaalin jyväsäilönnän tapaan ja tiiviisti suljettu siilo) sekä kaksi säilöntäaikaa (3 ja 12 viikkoa). Kullakin käsittelyllä tehtiin kolme rinnakkaissiiloa eli yhteensä 36 siiloa. Kutakin säilöntäainekäsittelyä varten sekoitettiin $100 \mathrm{~g}$ hukkakauran siemeniä ja 900 g ohran jyviä, joihin levitettiin säilöntäaineet: 99-prosenttista propionihappoa $1 \%$ tai ureaa 2,5 \% viljan tuorepainosta. Urea levitettiin vesiliuoksena. Hukkakauran siemeniä säilöttiin ohran jyvien seassa 300-400 siementä/siilo. Lisäksi säilöntäaineella käsitellyistä eristä erotettiin noin 50 hukkakauran siementä pintanäytteeksi avoimiin siiloihin. Hukkakauran siementen itävyys määritettiin Eviran Tutkimus- ja analytiikkaosaston Kasvianalytiikkayksikön laboratoriossa Loimaalla ja säilöntälaatuanalyysit tehtiin MTT:n Eläinravitsemusryhmän laboratoriossa Jokioisilla.

Hukkakauran itävyys oli säilöttäessä 61 \%. Kaikissa propionihapolla ja urealla säilötyissä suljetuissa ilmatiiviissä siiloissa hukkakauran itävyys oli hävinnyt kolmessa viikossa. Avoimien siilojen pintaosassa parin sentin syvyydessä itävyys säilyi osassa siemeniä, mutta syvemmällä olleiden siementen itävyys oli tuhoutunut. Propionihapolla säilöttyjen avoimien siilojen pinnassa oli itäviä hukkakauran siemeniä 3 viikon säilönnän jälkeen, mutta ei enää 12 viikon jälkeen. Urealla säilöttäessä pinnassa oli vielä 12 viikon säilönnän jälkeen yksi itävä siemen. Ilman säilöntäainetta jyväsäilötty hukkakaura ei menettänyt itävyyttään avoimessa eikä ilmatiiviisti suljetussa siilossa 3 viikon eikä 12 viikon säilönnän jälkeen, mutta itävyys väheni suljetussa ilmatiiviissä siilossa 16 prosenttiin 12 viikossa. Pidempää säilytystä ei tutkittu.

Tulosten perusteella propionihapolla ja urealla jyväsäilötyn hukkakauran itävyys häviää edellyttäen, että säilöntä tehdään huolellisesti ja siilo/auma/kasa peitetään tiiviisti. Avoimeen pintaan jäävät hukkakauran siemenet ovat riski, koska niiden itävyys voi säilyä todennäköisesti pinnan kuivumisen ja säilöntäaineen haihtumisen vuoksi. Erityinen riski on avoimeen kasaan ilman vaikutuksen alaiseksi jääneet hukkakauran siemenet, sillä dormanssi (itämislepo) saattaa suojata niitä itämiskykyisinä kauan.

Vilja puidaan jyväsäilönnässä normaalia aiemmin, mutta osa hukkakauran siemenistä on jo saattanut varista. Toisaalta uudet sivuversot ennättävät tuottaa itämiskykyisiä siemeniä. Maahan varisseet siemenet voivat itää ja tuottaa itäviä siemeniä vielä syksyn aikana, joten hukkakaurainen alue pitää käsitellä glyfosaattivalmisteella tai muokata mekaanisesti torjuntasuunnitelman mukaan.

Asiasanat: hukkakaura, Avena fatua, itävyys, jyväsäilöntä, propionihappo, urea, ilmatiivis säilöntä 


\section{Johdanto}

Laki velvoittaa torjumaan hukkakauraa (Avena fatua L.). Sen esiintymisestä pitää ilmoittaa tukihaun yhteydessä ja sen jälkeenkin kunnan maaseutuelinkeinoviranomaiselle, joka suorittaa katselmuksen ja antaa torjuntaohjeet ja/tai tekee torjuntasuunnitelman (Laki hukkakauran torjunnasta 185/2002 ja Maaja metsätalousministeriön asetus hukkakauran torjunnasta 326/2002). Lain täytäntöönpanon ja säännösten noudattamisen valvonnasta vastaa Elintarviketurvallisuusvirasto Evira. Hukkakaura on ensisijaisesti torjuttava kitkemällä, viljelyteknisin keinoin tai kemiallisesti. Jos kasvukauden aikana todetaan hukkakauraa niin runsaasti, ettei sitä pystytä kitkemään ja kemiallista torjuntaa ei ole tehty tai se on epäonnistunut tai viljelytekniikka ei salli sitä, kuten luomutuotannossa, on turvauduttava kasvuston hävittämiseen niittämällä ja sen jälkeen polttamalla tai muuten hävittämällä siten, ettei hukkakaura pääse leviämään. Tuet voidaan evätä tai niitä voidaan leikata, jos lohko on niin hukkakauran saastuttama, että siltä ei voi tuottaa markkinakelpoista tavaraa (Evira 2009). Sadon menetyksestä ja siihen uhratuista panoksista, tukien hylkäämisestä sekä hävityksen aiheuttamista kustannuksista aiheutuva taloudellinen menetys viljelijälle on siten erittäin merkittävä, tuhansia euroja riippuen hukkakauran saastuttamasta pinta-alasta.

Viljelijöiden tietämys hukkakauraongelmasta ja vastuullinen suhtautuminen torjuntatoimenpiteisiin on perusedellytys hukkakauran leviämisen estämiseksi. Yleisessä tukipolitiikassa pitäisi olla myös työkalut hukkakauran torjuntaan kannustamiseen pelkkien sanktioiden sijaan (MMM 2007). Ratkaisu näihin erityistapauksiin, ei yleiseksi torjuntakeinoksi, voisi olla kasvuston korjaaminen kukinnan jälkeen kokoviljasäilörehuksi tai viljan tuoresäilöntä, jolloin sadon korjuuvelvoite täyttyy eikä tukia ja satoa menetetä. Kokoviljasäilörehussa säilötään koko viljakasvi korsineen ja tähkineen taikinatuleentumisvaiheessa nurmirehun tapaan samoilla säilöntäaineilla ja koneilla. Harkerin ym. (2003) mukaan kokoviljan korjuu säilörehuksi voi vähentää hukkakauraa. Toisen kanadalaistutkimuksen mukaan laakasiiloon säilötyn kokoviljaohran sisään (1 m pohjasta, 2,5 m korkeassa siilossa) nailonpusseissa säilötyt hukkakauran siemenet menettivät itävyytensä kahdeksassa viikossa (Blackshaw ja Rode 1991). Suomessa tehdyssä kaksivuotisessa laajassa kokoviljan säilöntätutkimuksessa (Saarisalo ym. 2008) hukkakauran itävyys hävisi kolmen kuukauden säilönnän jälkeen niin laboratoriosiiloissa kuin ohrakasvustosta tehdyssä pyöröpaalisäilörehussakin. Kolmen viikon säilönnässä itävyys ei vielä hävinnyt, vaan paalien pintaosassa oli paljon itäviä hukkakauran siemeniä, kun rehu oli tehty neljän viikon päästä röyhylle tulosta, taikinatuleentumisen loppuvaiheessa. Hukkakauran siemenet kehittyvät nopeasti ja tuleentuneet siemenet varisevat herkästi, joten korjuu on tehtävä kahden viikon sisällä röyhylle tulosta ja säilöntäajan tulee olla vähintään kolme kuukautta.

Viljan tuoresäilöntämenetelmät, jyvä- ja murskesäilöntä ovat varteenotettavia vaihtoehtoja kuivatukselle öljyn hinnan kallistuessa (Huhtanen 1988, Palva ja Siljander-Rasi 2003, Palva 2005). Jyväsäilönnässä vilja säilötään kokonaisina jyvinä propionihapolla, urealla tai ilmatiiviisti ilman säilöntäainetta. Propionihappo tai ureasta ureaasientsyymin vaikutuksesta vapautuva ammoniakki tuhoavat ja estävät homeiden ja muiden haitallisten mikrobien kasvua. Säilöntäaineen annostusmäärä riippuu viljan kosteudesta. Ilmatiivis (kaasutiivis) säilöntä perustuu anaerobisiin olosuhteisiin hapen kuluessa loppuun pääosin mikrobien ja osaksi jyvien hengityksen seurauksena hiilidioksidin määrän noustessa samalla. Hapen puutteessa useimpien haitallisten mikrobien toiminta vähenee tai loppuu (Nash 1985). Murskesäilönnässä vilja (kosteus 35-45 \%) litistetään valssimyllyllä ja säilötään samoilla muurahaishappohjaisilla säilöntäaineilla kuin nurmirehut tai sokeripitoisella melassilla tai heralla säilymisen perustuessa happamuuteen ja hapettomuuteen. Jyväsäilötty vilja litistetään ennen eläimille syöttöä.

Jyväsäilöttäessä vilja puidaan myöhemmin kuin korjataan kokoviljasäilörehua tehtäessä ja itävien hukkakauran siementen riski on suurempi. Tuoresäilönnässä vältetään kuivurin kautta tuleva hukkakauran leviämisriski. Kostean viljan käsittely propionihapolla on erinomaista rehua eläimille, mutta se ei ole sopiva siemenviljalle, jonka elinkyvyn se tuhoaa. Samoin ilmatiiviissä säilönnässä viljan itävyys vähenee (Nash 1985, Brooker ym. 1992). Urealannoituksen haitallisen vaikutuksen siemenen itävyyteen on osoitettu johtuvan ammoniakista, jota muodostuu urean hydrolyysissä ureaasientsyymin vaikutuksesta (Bremner ja Krogmeier 1989).

Hukkakauran säilöntätutkimusten tarkoituksena oli tuottaa tietoa hukkakauran leviämiseen liittyvistä riskeistä, joiden perusteella viranomainen voi tarkentaa hukkakauran torjumiseksi annettavia ohjeita kasvuston korjuusta, säilönnästä ja käytöstä eläinten rehuna. Tässä tutkimuksessa selvitettiin säilyykö hukkakauran siementen itävyys propionihapolla, urealla tai ilmatiiviisti ilman säilöntäainetta jyväsäilötyssä viljassa. 


\section{Aineisto ja menetelmät}

Hukkakaura kerättiin yksityiseltä maatilalta hukkakauran saastuttamasta ohrakasvustosta 1.8.2007 ennen ohran puintia varisemisen estämiseksi. Koko kasvi irrotettiin maasta ja juuriosa leikattiin pois hävitettäväksi. Kasviin jätettiin mahdollisimman paljon kortta hukkakauran siementen jälkituleentumisen edistämiseksi. Hukkakaurakasvit levitettiin kuivumaan muovin päälle betonilattialle huoneeseen, jonka lämpötila vaihteli välillä $18-22{ }^{\circ} \mathrm{C}$ ja suhteellinen kosteus $62-85 \%$. Hukkakauran siemenet varisteltiin röyhyistä ennen säilöntää ja niistä otettiin näytteet itävyys- ja koostumusanalyysiin. Itävyys määritettiin 400 siemenestä. Säilönnässä käytetyn ohran (kaksitahoinen Annabell-lajike) kuiva-aineen kehitystä seurattiin Wile-kosteusmittarilla. Ohra puitiin 25 \%:n kosteudessa MTT:n pellolta Jokioisilla 16.8.2007 ja säilöttiin hukkakauran siementen kanssa pieniin koesiiloihin (120 ml:n lasipullo). Kokeessa oli kolme säilöntäainekäsittelyä (ilman säilöntäainetta, propionihappo ja urea), kaksi siilon sulkemistapaa (avoin normaalin jyväsäilönnän tapaan ja tiiviisti korkilla suljettu siilo) sekä kaksi säilöntäaikaa (3 ja 12 viikkoa). Kullakin koekäsittelyllä tehtiin kolme rinnakkaissiiloa, yhteensä 36 siiloa. Kutakin kolmea säilöntäainekäsittelyä varten sekoitettiin 100 g hukkakauran siemeniä ja 900 g ohran jyviä, joihin levitettiin säilöntäaineet: 99-prosenttista propionihappoa $1 \%$ tai ureaa $2,5 \%$ viljan tuorepainosta. Urea liuotettiin ensin kuumaan veteen (2/5 ureaa ja 3/5 vettä) ja levitettiin vesiliuoksena. Hukkakauran siemeniä säilöttiin ohran jyvien seassa 300-400 siementä/siilo. Lisäksi säilöntäaineella käsitellyistä eristä erotettiin noin 50 hukkakauran siementä pintanäytteeksi avoimiin siiloihin parin sentin paksuudelta ja päälle kerros ohran jyviä. Siilot varastoitiin pimeässä (peitettynä) samassa huonetilassa kuin hukkakaurat ennen säilöntää. Siilot tyhjennettiin 21 ja 84 vuorokauden kuluttua säilönnästä. Hukkakauran siemenet eroteltiin itävyysmääritykseen, pinnassa olevat hukkakaurat erikseen. Loppuosasta eli ohran jyvistä tehtiin typpi- ja säilöntälaatuanalyysit: $\mathrm{pH}$, haihtuvat rasvahapot (VFA), pelkistävät sokerit ja ammoniumtyppi sekä urealla säilötyistä urea.

Hukkakauran siementen itävyys määritettiin Eviran Tutkimus- ja analytiikkaosaston Kasvianalytiikkayksikön laboratoriossa Loimaalla. Koostumus- ja säilöntälaatuanalyysit tehtiin MTT:n Eläinravitsemusryhmän laboratoriossa Jokioisilla.

\section{Tulokset ja tulosten tarkastelu}

\section{Hukkakauran itävyys ja koostumus säilöttäessä}

Hukkakauran siementen itävyys oli säilöttäessä 61 \% ja 100 siemenen paino oli 2,5 g (n=6). Säilötyssä erässä oli erikokoisia ja -värisiä hukkakauran siemeniä tuleentumisasteesta riippuen. Niistä pienet vaaleat hukkakauran siemenet, joiden 100 siemenen paino oli vain 0,9 g, itivät kuitenkin yhtä hyvin (53 \%) kuin isot vaaleat (52 \%). Tummien siementen itävyys oli paras (71 \%). Pienissä hukkakauran siemenissä oli enemmän kuorta, kuitua ja ligniiniä ja vielä vähemmän tärkkelystä kuin säilötyssä hukkakauraerässä keskimäärin ja se oli huonompaa ravintoarvoltaan kuin huono katokaura (Taulukko 1). Ohran kuiva-ainepitoisuus säilöttäessä oli $24 \%$.

Taulukko 1. Hukkakauran koostumus jyväsäilöntäkokeessa verrattuna kahteen eri laatuiseen viljeltyyn rehukauraan.

\begin{tabular}{|c|c|c|c|c|c|c|c|}
\hline & Tuhka & $\begin{array}{l}\text { Raaka- } \\
\text { valkuai- } \\
\text { nen }\end{array}$ & $\begin{array}{l}\text { Raaka- } \\
\text { rasva }\end{array}$ & $\begin{array}{l}\text { Tärkke- } \\
\text { lys }\end{array}$ & $\mathrm{NDF}^{1)}$ & $\mathrm{ADF}^{2)}$ & Ligniini \\
\hline Hukkakaura, jyväsäilötty & 41 & 115 & 74 & 344 & 440 & 210 & 38 \\
\hline Hukkakaura, pienet vaaleat ${ }^{*}$ & 44 & 103 & 62 & 237 & 541 & 266 & 48 \\
\hline Ohra, jyväsäilötty & 28 & 80 & 20 & 615 & 187 & 60 & 0,6 \\
\hline \multicolumn{8}{|l|}{ Viljelty rehukaura } \\
\hline Kaura, 61 kg/hl ${ }^{3)}$ & 28 & 103 & 72 & 476 & 288 & 123 & 28 \\
\hline Kaura, 33 kg/hl ${ }^{3)}$ & 30 & 109 & 63 & 246 & 520 & 233 & 37 \\
\hline
\end{tabular}




\section{Hukkakauran itävyys säilönnän jälkeen}

Kaikissa propionihapolla ja urealla säilötyissä suljetuissa siiloissa hukkakauran siementen itävyys oli hävinnyt kolmessa viikossa. Sen sijaan avoimien siilojen pintaosassa parin sentin syvyydessä itävyys säilyi osassa hukkakauran siemeniä, mutta syvemmällä olleiden siementen itävyys oli tuhoutunut. Propionihapolla säilöttyjen avoimien siilojen pinnassa oli itäviä hukkakauran siemeniä 3 viikon säilönnän jälkeen, mutta ei enää 12 viikon säilönnän jälkeen. Urealla säilöttäessä pinnassa oli vielä 12 viikon säilönnän jälkeen yksi itävä siemen. Ilman säilöntäainetta jyväsäilötty hukkakaura ei menettänyt itävyyttään avoimessa eikä ilmatiiviisti suljetussa siilossa 3 viikon eikä 12 viikon säilönnässä, mutta itävyys väheni suljetussa ilmatiiviissä siilossa 12 viikon säilönnässä (Taulukko 2).

Ilmatiiviisti suljetuissa ilman säilöntäainetta säilötyissä siiloissa muodostui myös kaasua, sillä hiilidioksidin määrä lisääntyy ilmatiiviissä säilönnässä. Propionihapolla ja urealla säilötyissä siiloissa ei muodostunut kaasua. Nashin (1985) mukaan viljan alkio kuolee hapen puutteeseen ilmatiiviissä säilönnässä, mutta itävyyden vähenemisen nopeus vaihtelee paljon. Itämiskyvyn heikkeneminen on nopeampaa kosteammassa viljassa kuin kuivassa viljassa. Kosteuspitoisuuden ollessa 17 \% oli itämiskykyä jäljellä vielä kolmen kuukauden varastoinnin jälkeen. Nyt tehdyssä tutkimuksessa hukkakauran siemenet eivät menettäneet kokonaan itävyyttään kolmessa kuukaudessa, kun ilmatiiviisti säilötyn ohran kosteus säilönnän jälkeen oli $22 \%$. Hukkakauran itävyys kuitenkin väheni 61:sta prosentista 16 prosenttiin. Hukkakaura saattaa olla vastustuskykyisempi kuin viljellyt viljat. Säilöntäaika olisi pitänyt olla pidempi hukkakauran itävyyden säilymisen selvittämiseksi ilmatiiviissä säilönnässä. Avoimissa ilman säilöntäainetta säilötyissä siiloissa hukkakauran itävyys oli vielä kolmen kuukauden päästä korkea. Käytännössä avoimessa kasassa ilman säilöntäainetta säilötty vilja ei tule kysymykseen, sillä se pilaantuu. Tässä kokeessa ilman säilöntäainetta säilötyt avoimissa siiloissa olleet siemenet olivat tunkkaisen, homeisen hajuisia ja osin homeisia ohran jyviä oli nähtävissä. Jos hukkakauran siemeniä jää esimerkiksi kitkemisen jälkeen avoimeen kasaan ilman vaikutuksen alaiseksi, aiheuttavat ne selvän leviämisriskin. Vahva dormanssi suojaa hukkakauran siemeniä viljeltyjä viljoja paremmin sekä pilaantumiselta että itävyyden menetykseltä. Hannukkalan ja Huhtasen (1986) tutkimuksissa ohran itävyyden ollessa noin $20 \%$ korjuun jälkeen, korkein 2,5 \%:n ureakäsittely esti ohran itävyyden kahden viikon jälkeen ja pienin ( $1 \%$ ureaa) kahdeksassa viikossa, mutta ohrassa esiintyi hometta, kun kosteus oli $32 \%$. Hukkakauran siemenet menettivät itävyyden ammoniakin vesiliuoksessa $(0,2 \%)$ nopeasti (Rieder 1966).

Taulukko 2. Hukkakauran idätettyjen siementen määrä ja itävyys 3 ja 12 viikon jälkeen säilönnästä

\begin{tabular}{|c|c|c|c|c|}
\hline \multirow[b]{2}{*}{ Säilöntäkäsittely } & \multicolumn{2}{|c|}{3 viikon jälkeen säilönnästä } & \multicolumn{2}{|c|}{12 viikon jälkeen säilönnästä } \\
\hline & $\begin{array}{l}\text { Idätetty } \\
\text { kpl }\end{array}$ & $\begin{array}{l}\text { Itävyys } \\
\%\end{array}$ & $\begin{array}{l}\text { Idätetty } \\
\text { kpl }\end{array}$ & $\begin{array}{l}\text { Itävyys } \\
\%\end{array}$ \\
\hline \multicolumn{5}{|l|}{ Ei säilöntäainetta } \\
\hline Avoin siilo & 1200 & 90 & 1053 & 86 \\
\hline Suljettu siilo & 1186 & 88 & 1102 & 16 \\
\hline \multicolumn{5}{|l|}{ Propionihappo } \\
\hline Avoin siilo, pinta & 159 & 3 & 155 & 0 \\
\hline Avoin siilo, pinnan alla & 1150 & 0 & 1107 & 0 \\
\hline Suljettu siilo & 1135 & 0 & 1207 & 0 \\
\hline \multicolumn{5}{|l|}{ Urea } \\
\hline Avoin siilo, pinta & 158 & 13 & 162 & 1 \\
\hline Avoin siilo, pinnan alla & 1060 & 0 & 1095 & 0 \\
\hline Suljettu siilo & 1084 & 0 & 1497 & 0 \\
\hline
\end{tabular}

Tulosten perusteella propionihapolla ja urealla jyväsäilötyn hukkakauran itävyyden häviäminen edellyttää, että siilo/auma/kasa peitetään tiiviisti. Tämä ei vastaa yleisiä jyväsäilöntäohjeita, joiden mukaan 
peittäminen ei ole tarpeellista. Peittäminen on kuitenkin hukkakauran esiintyessä tärkeää, koska avoimeen pintaan jäävät hukkakauran siemenet voivat säilyä itämiskykyisinä ja muodostavat erityisen leviämisriskin. Itävyyden säilyminen johtuu todennäköisesti pinnan kuivumisesta ja säilöntäaineen haihtumisesta. Myös rehuhygienian kannalta peittäminen on suotavaa lintujen, hiirien, myyrien ym. aiheuttaman likaamisen vuoksi. Jos on epäilystä, että vilja sisältää hukkakauran siemeniä, on se peitettävä tiiviisti. Myös ilmatiiviisti ilman säilöntäainetta jyväsäilötty hukkakauraa sisältävä vilja on riskimateriaalia ainakin kolmen kuukauden ajan säilönnästä. Pidempää säilytystä ei tässä tutkittu. Lisätutkimuksia tarvitaan selvittämään missä ajassa hukkakauran itävyys häviää ilmatiiviissä säilönnässä vai häviääkö se ollenkaan.

Taulukossa 3 on esitetty jyväsäilöttyjen ohrien säilönnällinen laatu. Avoimien ja suljettujen siilojen välillä oli koostumuksessa hyvin vähän eroa, siksi tulokset on esitetty vain säilöntäainekäsittelyittäin eri aikoina. Säilönnän aikana tapahtui hyvin vähän käymistä. Etikkahappoa muodostui vähän kaikilla käsittelyillä ja maitohappoa vain urealla säilötyssä ohrassa. Propionihapolla säilöttäessä pH oli alin ja viljassa oli selvä propionihapon haju. Propionihappoa oli 6,8 g/kg ka, joka on suoraan käytettävissä eläimen energialähteenä. Propionihappo on normaali pötsiaineenvaihdunnan lopputuote. Ureasäilönnällä $\mathrm{pH}$ oli korkein emäksisen ammoniakin vuoksi, jonka selvä haju oli aistittavissa. Kaikki urea ei ollut hajonnut ammoniakiksi, vaan sitä oli jäljellä vielä ureana. Märemmässä viljassa urea olisi todennäköisesti hajonnut enemmän ammoniakiksi. Ureasäilöntä lisäsi ohran typpipitoisuuden noin kaksinkertaiseksi niin, että raakavalkuaispitoisuus lisääntyi 166-173 grammaan/kg ka. Ammoniakkipitoisuus tuoreessa ohrassa oli 0,2 $-0,3 \%$.

Taulukko 3. Jyväsäilöttyjen ohrien käymislaatu ja urea- ja raakavalkuaispitoisuus

\begin{tabular}{|c|c|c|c|c|c|c|c|c|}
\hline \multirow[t]{2}{*}{ Säilöntäkäsittely } & \multirow[t]{2}{*}{$\mathrm{pH}$} & Sokeri & $\begin{array}{l}\text { Maito- } \\
\text { happo }\end{array}$ & $\begin{array}{l}\text { Etikka- } \\
\text { happo }\end{array}$ & $\begin{array}{l}\text { Propio- } \\
\text { nihappo }\end{array}$ & \multirow{2}{*}{$\begin{array}{l}\mathrm{NH}_{4}-\mathrm{N} \\
-\mathrm{g} / \mathrm{kg} \mathrm{N}-\end{array}$} & Urea & $\begin{array}{l}\text { Raaka- } \\
\text { valkuai- } \\
\text { nen }\end{array}$ \\
\hline & & \multicolumn{4}{|c|}{----------------------g/kg ka--------------------- } & & \multicolumn{2}{|c|}{------g/kg ka------ } \\
\hline \multicolumn{9}{|c|}{3 viikkoa säilönnän jälkeen } \\
\hline Ilman säilöntäainetta & 6,56 & 24 & 0 & 1,0 & 0,1 & 1,2 & & 81 \\
\hline Propionihappo & 5,14 & 27 & 0 & 1,3 & 6,8 & 1,7 & & 81 \\
\hline Urea & 8,59 & 13 & 1 & 1,0 & 0,0 & 94 & 21 & 173 \\
\hline \multicolumn{9}{|c|}{12 viikkoa säilönnän jälkeen } \\
\hline Ilman säilöntäainetta & 6,48 & 18 & 0 & 0,6 & 0,1 & 1,7 & & 86 \\
\hline Propionihappo & 5,20 & 31 & 0 & 1,1 & 6,8 & 2,8 & & 85 \\
\hline Urea & 8,53 & 15 & 1,6 & 1,7 & 0,1 & 110 & 18 & 166 \\
\hline
\end{tabular}

\section{Johtopäätökset}

Hukkakaura menetti itävyytensä propionihapolla tai urealla jyväsäilötyssä viljassa tiiviisti suljetuissa siiloissa kolmessa viikossa. Sen sijaan avoimien siilojen pinnassa oli itäviä hukkakauran siemeniä. Hukkakauran siementen itävyyden häviäminen propionihappo- ja ureakäsittelyssä edellyttää, että siilo/auma/kasa peitetään tiiviisti. Peittäminen ei vastaa jyväsäilönnän yleisiä ohjeita, mutta se on hukkakauran esiintyessä välttämätöntä. Avoimeen pintaan jäävät hukkakauran siemenet voivat säilyä itämiskykyisinä ja aiheuttaa leviämisriskin. Säilöntäaineen annostus riippuu viljan kosteudesta. Riittävä säilöntäaineen määrä ja annostustarkkuus ovat edellytyksiä onnistuneelle säilönnälle. Ilmatiiviissä säilönnässä ilman säilöntäainetta hukkakauran itävyys väheni, mutta ei hävinnyt kolmen kuukauden tutkimusaikana. Erityinen riski on avoimeen kasaan ilman vaikutuksen alaiseksi jääneet hukkakauran siemenet, sillä ne säilyttävät itävyytensä. Tämän tutkimuksen perusteella huolellinen viljan jyväsäilöntä propionihapolla tai urealla saattaa erityistapauksissa viranomaisen salliessa sopia hukkakauraisen kasvuston korjuuseen, jolloin korjuuvelvoite täyttyy eikä tukia ja satoa menetetä. Vaikka vilja puidaan jyväsäilönnässä normaalia aikaisemmin, on osa hukkakauran siemenistä ehtinyt varista. Toisaalta uudet sivuversot ennättävät tuottaa itämiskykyisiä siemeniä. Maahan varisseet siemenet voivat itää ja tuottaa itäviä siemeniä vielä syksyn aikana, joten hukkakaurainen alue pitää käsitellä glyfosaattivalmisteella tai muokata mekaanisesti torjuntasuunnitelman mukaan. 


\section{Kirjallisuus}

Brooker, D.B., Bakker-Arkema, F.W. \& Hall, C.W. 1992. Drying and storage of grain and oilseeds. ISBN 0-442-20515-5. p. 4-5.

http://www.google.com/books?id=qX-

BaufhXKoC\&printsec=frontcover\&hl=fi\&source=gbs_v2_summary_r\&cad=0\#v=onepage\&q=\&f=false

Blackshaw, R. E. \& Rode, L. M. 1991. Effect of ensiling and rumen digestion by cattle on weed seed viability. Weed Science 39: 104-108.

Bremner, J.M. \& Krogmeier, M.J. 1989. Evidence that the adverse effect of urea fertilizer on seed germination in soil is due to ammonia formed through hydrolysis of urea by soil urease. The Proceedings of the National Academy of Sciences USA 86: 8185-8188.

Evira 2009. Hukkakauran torjunta on rahanarvoinen ratkaisu. Viitattu 27.11.2009.

http://www.evira.fi/attachments/kasvintuotanto_ja_rehut/siemenet/siemenohjeet/hukkakauran_torjunta_on_rahan arvoinen_ratkaisu_uusin.pdf

Harker, K.N., Kirkland, K.J., Baron, V.S. \& Clayton, G.W. 2003. Early-harvest barley (Hordeum vulgare) silage reduces wild oat (Avena fatua) densities under zero tillage. Weed Technology 17: 102-110.

Huhtanen, P. 1988. Rehuviljan säilöntämenetelmät. Teoksessa: Rehuviljan tuoresäilöntä Maatalouskeskusten Liiton julkaisuja no 761: Tieto tuottamaan 50: 19-29. ISSN 0355-1296.

Hannukkala, A. \& Huhtanen, P. 1986. Urea treatment of barley grain. Effect on storage properties and fungal growth. Journal of Agricultural Sciene in Finland 58: 197-208.

Laki hukkakauran torjunnasta 185/2002. http://www.finlex.fi/fi/laki/alkup/2002/20020185

MMM 2007. Selvitys hukkakauralainsäädännön vaikutuksista 2007. Työryhmämuistio MMM 2007:18. 12 s. Helsinki 2007. ISBN 978-952-453-350-8, ISSN 0781-6723

http://www.mmm.fi/attachments/mmm/julkaisut/tyoryhmamuistiot/2007/5tFetMb8q/trm2007_18_Hukkakaurase lvitys_lopullinen_versio.pdf

MMM asetus hukkakauran torjunnasta 326/2002. http://www.finlex.fi/fi/laki/alkup/2002/20020185

Nash, M.J. 1985. Crop conservation and storage in cool temperate climates. Second edition. Oxford. Pergamon Press Ltd. ISBN 0-08 029809-5. 286 p.

Palva, R. 2005. Tuoresäilöntämenetelmät. Teoksessa: Reetta Palva, Anna-Maija Kirkkari, Hanne Teräväinen (toim.). Viljasadon käsittely ja käyttö: Viljan tuoresäilöntä. ProAgria Maaseutukeskusten Liiton julkaisuja nro 1012: Tieto tuottamaan 108: 55-59. ISSN 0357-7295.

Palva, R. \& Siljander-Rasi, H. 2003. Kuivaamattoman viljan käyttö lihasikoja kasvattavalla tilalla. Työtehoseuran julkaisuja 388. 59 p.

Rieder, R. 1966. Der Einfluss des Schwemmistes auf die Unkrautverbreitung und die Anwendung der Tetrazolium-Methode bei Unkrautsamen. Dissertation, Landwirtschaftlichen Hochschule Hohenheim 119 p.

Saarisalo, E., Heikkilä, T., Jalli, H., Poikulainen, J., Köylijärvi, S. \& Jaakkola, S. 2008. Hukkakauran siementen itävyyden säilyminen kokoviljasäilörehussa. Teoksessa: Leena Rantamäki-Lahtinen (toim.). Maataloustieteen Päivät 2008, 10.-11.1.2008, Viikki, Helsinki: esitelmä- ja posteritiivistelmät. Suomen maataloustieteellisen seuran tiedote 24: p. 107. http://www.smts.fi/mpol2008/index_tiedostot/Esitelmat/es085.pdf 